\title{
Changes in Lipid Content of the Montane Vole
}

\author{
Paul ROCK \& Olwen WILLIAMS ${ }^{1}$
}

\begin{abstract}
Rock P. \& Williams O., 1979: Changes in lipid content of the montane vole. Acta theriol., 24, 18: 237-247 [With 2 Tables]

To determine the influence of cold and reduced food supply on the fat content of montane voles Microtus montanus nanus (M erriam, 1891) a number of these animals were exposed under controlled laboratory conditions to eight combinations of ambient temperature and food availability (ad libitum, maintenance and one-half maintenance rations, and starvation at $5^{\circ} \mathrm{C}$ and $26^{\circ} \mathrm{C}$ ). The maintenance ration was based on the apparent digestible energy of an accustomed diet, the weight of individuals at the beginning of the experiment, and their calculated temperature-dependent metabolic rates. Ration levels and the interaction of low temperature and ration levels significantly influenced fat reserves. Survival was significantly correlated with terminal fat indices and with ration levels but not with temperature alone. No significant interaction was found between temperature and ration levels. Linear regression equations were obtained showing the relation between fat and water, lean dry, stomach-free, and total weights. Results were consistent with the role of fat as an energy store utilized in response to environmental stress.

[Dept. EPO Biology, Univ. Colorado, Boulder, Colorado 80309, U.S.A.]
\end{abstract}

\section{INTRODUCTION}

The body fat of rodents may be viewed as a store of metabolic energy which can be mobilized in response to caloric demands imposed by environmental and physiological stressors such as cold, reduced food supply, or onset of breeding. Fat levels may serve as an index to the physiological condition of an individual or a population. Depleted reserves may indicate that an individual or a population has experienced stress; adequate reserves may indicate that it has not ( $\mathrm{H} \mathrm{e} \mathrm{r} \mathrm{o} \mathrm{ux,} \mathrm{1961;}$ Caldwell \& Caldwell, 1968; Sawicka-Kapusta, 1968; Fleharty et al., 1973; Kołodziej-Banach, 1976).

Some rodents seem to have evolved mechanisms which function to increase energy reserves in anticipation of recurrent stressful periods; hence they exhibit annual cycles of total body fat (S e a l a n d e r, 1951, 1972; H eroux, 1961, H ow a d, 1951; B e r ger o n, 1976; K o$\nmid$ odziej-Banach, 1976). In others, changes have been most pro-

1 To whom requests for reprints should be directed. 
nounced in the lipid content of brown adipose tissue (D i d o w \& $\mathrm{H}$ a yw a rd, 1969; S e a l a nder, 1972). Still other populations show no distinct cycles (H is s a \& T a rkk on en, 1969; Evans, 1973; Fleh a rty et al., 1973; P u cek, 1973). To what extent these observations are a function of time of sampling, frequency of sampling, and sample size is not apparent. Nonetheless, annual lipid cycles seem to be of frequent occurrence and $\mathrm{Fleharty}$ et al. have suggested that this pattern is a general one for small rodents in the temperate zone.

Evidence that fat can be mobilized from adipose tissues in response to cold or starvation is found in laboratory studies on body composition and blood levels of free fatty acids in Rattus and Mus (W iddowson \& McCance, 1956; Frederickson \& Gordon, 1958; Elkington \& Widdowson, 1959; Ba ur \& Filer, 1959; H u th \& Elkington, 1959; Kleiber, 1961; Brodie et al., 1965). During short-term cold-stress, utilization of fat seems to be mediated through the autonomic nervous system and catecholamines (B a b in e a $\mathrm{u} \& \mathrm{P}$ a g e, 1955; Hannon \& Larson, 1961; Gilgen et al., 1962; Schonba um et al., 1962; Hannon et al., 1963; Brodie et al., 1965). However, information regarding the immediate effects of cold and starvation on voles is scarce. Hence, in this study we examined, under controlled laboratory conditions, the impact of these stressors on total body fat in the montane vole, Microtus montanus nanus (M e r ria m, 1891). A number of these voles were exposed to eight combinations of ambient temperature and food availability. Following the test period, the animals, were sacrificed and their fat content determined. Later, equations were derived describing the relationship between the fat, water, and lean dry components and wet weights.

\section{PROCEDURE}

Voles used in this study were adult animals captured in montane meadows between $2170 \mathrm{~m}$ and $3100 \mathrm{~m}$ elevation in Boulder and Eagle Counties, Colorado, during the summer and early fall of 1972. In the habitats in which they were trapped, montane voles are sympatric with long-tailed voles ( $M$. longicaudus). Although these species are supposed to be distinguishable on differences in headtrunk/tail length ratios ( $\mathrm{Hall}$ \& $\mathrm{Kels}$ o $\mathrm{n}, 1959$ ), we have found much overlap in these measurements. Therefore, we identified the montane voles on the basis of location of capture, general morphological characteristics, and the presence of palpable supraorbital ridges on the skull, easily discernible in live individuals and totally lacking in long-tailed voles (W illiams \& Bird, 1972). Identification was confirmed at the end of the experiment by examination of dental characters (L e chle it ner, 1969).

The field-caught voles were maintained in the laboratory for a minimum of eight weeks before the experimental period began. They were housed in single-sex 
groups of three to four individuals in tubs containing peat soil, hay, and cotton nesting material at $18^{\circ} \mathrm{C}$ under a $16 \mathrm{hr}$ dark: $8 \mathrm{hr}$ light photoperiod (Colvin \& C olvin, 1970). They were fed Purina Laboratory Chow, rolled barley, lettuce, and water ad libitum. We have found that voles appearing very thin at time of capture put on fat rapidly under these conditions.

In a preliminary experiment, a maintenance ration was developed based on the apparent digestible energy $(A D E)$ of the diet. The $A D E$ was determined by ascertaining, for six adult males and six adult females, the difference between the calculated energy content of the portions of barley, lettuce, and chow consumed daily ad libitum and the energy content of the feces ( $\mathrm{Klei}$ ber, 1961). Energy content of dietary components and daily fecal samples was found by bomb-calorimetry. Because urinary energy loss is small in voles, probably amounting to no more than five percent of their total energy intake (D r o żd ż, 1968; G ę b c z y ńs k a, 1970; M e e e, 1971), the value for $A D E$ was used as an estimate of energy assimilated. Mean assimilation efficiency values were calculated for each sex and $t$-tested for significance.

In the main experiment, conditions were chosen to simulate those of the winter environment of montane voles in Colorado and to provide suitable experimental controls. Two temperatures, $5^{\circ} \mathrm{C}$ and $26^{\circ} \mathrm{C}$, and four energy ration levels, ad libitum $(A D)$, maintenance $(M N)$, one-half maintenance $(1 / 2 M N)$ and no food, or starvation $(S)$, were arranged in orthogonal combinations providing eight different sets of conditions. The $5^{\circ} \mathrm{C}$ temperature was selected as a temperature within the range experienced by montane voles in their subnivean microhabitats in the winter (M a r r, 1968; Marr et al., 1968a, 1968b). The temperature of $26^{\circ} \mathrm{C}$ was chosen because it is within the thermoneutral zone of $M$. montanus ( $\mathrm{Packard}, 1968$ ). The $5^{\circ} \mathrm{C}$ temperature was provided by a walk-in cooler and the $26^{\circ} \mathrm{C}$ temperature by a storage room. No temperature fluctuations greater than $2^{\circ} \mathrm{C}$ were recorded in either location during the experiment.

The maintenance ration was calculated to provide just enough energy to meet the metabolic needs of the experimental animals and to serve as a control for the other ration levels. The ration fed each animals was based on the body weight of the individual at the beginning of the experiment and was not altered during its course. Rations, providing calories for 24 hours, were computed using the temperature-dependent metabolic rate and the $A D E$ of the diet (K le i ber, 1961). For each test temperature, the metabolic rate was calculated from the regression equation for metabolic rate in $M$. montanus $(Y=7.09-0.17 \mathrm{X}$, where $\mathrm{X}=$ ambient temperature in degrees C.) ( $\mathrm{P} \mathrm{a} \mathrm{c} \mathrm{k} \mathrm{a} \mathrm{r} \mathrm{d,} \mathrm{1968).}$

Four adults, two males and two females, were exposed to each set of conditions for 14 days. Animals were housed individually in $30 \times 41 \times 14 \mathrm{~cm}$ plastic containers fitted with tops of galvanized screening and provided with a peat-soil substrate and nesting material. The substrate and nesting material simulated conditions of the natural environment; in winter voles occupy globular nests of grasses on the ground surface. Each individual was weighed at the beginning and at the end of the experiment or upon death. From these individual values the mean percent change in body weight was calculated for each set of experimental conditions. Ideally, we should have known the initial fat content of the experimental animals, but, because this could only be directly established by extraction, we reasoned that the long holding period prior to the experiment insured adequate fat levels in all of them.

Survival time, measured in days, was recorded for animals dying before the 
end of the experiment. Animals which did not die during the experiment were killed at its termination and their survival time was recorded as 14 days.

Following the termination of the experiment and using standard procedures, the carcass of each vole was dried, ground, and its fat extracted in petroleum ether in a Labco Goldfisch Extraction Apparatus. The data obtained provided estimates of final body composition. Mean values (and S. D.) for water, lean dry, and fat components, and for fat index (grams fat/grams lean dry material = F. I.), percent weight change, and survival times were computed for each set of conditions. These were subjected to a two-way analysis of variance (ANOVA) and significant effects were subjected to multiple comparisons using $t$ - and Newman-Keuls tests. Later, to derive predictive equations for body fat in montane voles, grams of fat were regressed against grams of water, lean dry weight, final total weight, and stomach-free wet weight. Finally, regression equations for water and lean dry components were similarly obtained.

\section{RESULTS}

The preliminary experiment revealed that although the voles ate different amounts of each of the diet components, total consumption for each individual in terms of both weight of food and calories was similar. Additionally, a $t$-test showed no differences between the means for each sex $(p<0.05)$. The mean weight of feed consumed was $0.43 \pm 0.11$ $\mathrm{g} / \mathrm{g}$ body wt/day. The mean value for energy lost in the feces was $63.45 \pm 24.99 \mathrm{cal} / \mathrm{g}$ body wt/day. A $t$-test showed no significant differences between males and females $(p<0.05)$. The $A D E$ value of the diet varied between individuals ( $\bar{x}=898.39 \pm 444.13 \mathrm{cal} / \mathrm{g}$ ration), but, the assimilation efficiencies for all voles were high. All values were above $80 \%$ with a mean of $85.8 \pm 3.2 \%$. Again, a $t$-test showed no significant difference between sexes $(p<0.05)$.

All voles in the main experiment experienced a change in weight during its course. In general, the voles on the $A D$ ration gained weight at both temperatures, but all of the others lost weight. The smallest loss was that of animals on the $M N$ ration at $5^{\circ} \mathrm{C}(\bar{x}=-3.5 \pm 5.3 \%$ of initial weight) although one of the individuals on this ration lost eight times as much weight as any of the others accounting for the high S. D. The greatest loss of weight was experienced by starved animals at $5^{\circ} \mathrm{C}(\bar{x}=$ $-46.1 \pm 3.5 \%$ ). Although no weight loss was expected for voles on the $M N$ ration at either temperature, it presumably occurred because the $M N$ ration had been calculated on the basis of the apparent digestible energy of the diet rather than on the actual assimilated energy requirement of the voles. A two-way ANOVA revealed a significant ration effect but no significant temperature effect on percent weight lost. Using the Newman-Keuls test, multiple comparisons showed significant differences between all ration levels at both temperatures $(p<0.05)$. 
Body components were variously affected by the experimental conditions. Voles exposed to the most rigorous test conditions showed the lowest terminal fat levels; those under control conditions showed the highest (Table 1). Starvation at $5^{\circ} \mathrm{C}$ resulted in a mean F. I. of $0.10 \pm 0.02$

\section{Table 1}

Terminal fat indices (means and S. D.) of voles exposed to eight combinations of ration levels and temperature.

\begin{tabular}{lcc}
\hline Ration level & $5^{\circ} \mathrm{C}$ & $26^{\circ} \mathrm{C}$ \\
\hline Ad libitum & $1.12 \pm 0.26$ & $1.74 \pm 1.04$ \\
Maintenance & $0.67 \pm 0.54$ & $0.91 \pm 0.62$ \\
$1 / 2$ maintenance & $0.26 \pm 0.35$ & $0.32 \pm 0.33$ \\
Starvation & $0.10 \pm 0.02$ & $0.16 \pm 0.16$ \\
\hline
\end{tabular}

(fat $=3.1 \%$ stomach-free weight); voles on the $A D$ ration at $26^{\circ} \mathrm{C}$ emerged with a mean F. I. of $1.74 \pm 1.04$ fat $=32.1 \%$ stomach-free weight). A two-way ANOVA showed the effect of both temperature and ration levels to be significant $(p<0.01)$. Body water was significantly influenced by ration level and by the interaction of ration and temperature. It was lowest in animals held on the $A D$ ration at $26^{\circ} \mathrm{C}(\bar{x}=48.1 \pm 13.4 \%$ stomach-free weight) and highest for those starved at $26^{\circ} \mathrm{C}(\bar{x}=67.3 \pm$ $2.7 \%$ stomach-free weight $)(p<0.01)$. A negative correlation $(r=-0.81$; $p<0.01$ ) existed between fat and water. Presumably much of the weight lost by voles in the experiment was due to a decrease in relatively unhydrated fatty tissue. The lean dry component was significantly affected by ration level only; it was lowest for animals on the $A D$ diet at $26^{\circ} \mathrm{C}$ ( $\bar{x}=19.9 \pm 3.3 \%$ stomach-free weight) and highest for those starved at $5^{\circ} \mathrm{C}(\bar{x}=30.5 \pm 0.8 \%$ stomach-free weight $)(p<0.01)$.

Survival of voles was noticeably affected by the conditions to which they were exposed. All voles on the $A D$ ration at both temperatures and those on the $M N$ ration at $5{ }^{\circ} \mathrm{C}$ survived for the full 14 days of the experiment. All of those starved at both temperatures died in six or fewer days ( $\bar{x}$ survival time at $26^{\circ} \mathrm{C}=5.8 \pm 0.5$ da; $\bar{x}$ at $5^{\circ} \mathrm{C}=5.0 \pm 0.8 \mathrm{da}$ ). A two-way ANOVA showed the effect of ration level to be significant $(p<0.01)$; the effect of temperature alone and the interaction between temperature and ration were not. Survival was significantly correlated with terminal fat index $(r=0.56, \mathrm{df}=30, p<0.01)$.

Finally, the data obtained from this study, supplemented by values derived from a small sample of field-trapped voles, allowed us to generate linear regression equations describing the relationship between fat, lean dry, stomach-free and total weights. No equations seemed to be 
better (giving much higher $r$ and lower $p$ values) than those based on total wet weight (Table 2). Hence, because the latter is equivalent to live weight and because we need to be able to estimate fat levels in

Table 2

\begin{tabular}{|c|c|c|}
\hline & $\begin{array}{l}\text { Adult Males } \\
\mathrm{N}=18, \mathrm{df}=16\end{array}$ & $\begin{array}{l}\text { Adult Females } \\
\mathrm{N}=23, \mathrm{df}=21\end{array}$ \\
\hline Eq. 1 & $\begin{array}{l}\mathrm{Y}_{\boldsymbol{F}}=1.02 \quad \mathrm{X}_{W}-15.98 \\
r=0.89\end{array}$ & $\begin{array}{l}Y_{F}=1.11 \quad X_{W}-14.38 \\
r=0.56\end{array}$ \\
\hline Eq. 2 & $\begin{array}{l}Y_{F}=2.49 \quad X_{L D}-15.54 \\
r=0.74\end{array}$ & $\begin{array}{l}Y_{F}=3.28 \quad X_{L D}-20.02 \\
r=0.79\end{array}$ \\
\hline Eq. 3 & $\begin{array}{l}Y_{F}=0.47 \quad X_{T W}-11.26 \\
r=0.96\end{array}$ & $r \stackrel{Y_{F}=0.58 \quad X_{T W}-14.20}{0.94}$ \\
\hline Eq. 4 & $\begin{array}{l}\mathrm{Y}_{F}=0.46 \quad X_{S F W}-10.52 \\
\mathrm{r}=0.96\end{array}$ & $\begin{array}{l}\mathrm{Y}_{F}=0.57 \quad X_{S F W}-13.36 \\
\mathrm{r}=0.96\end{array}$ \\
\hline
\end{tabular}

living populations, these equations were identified as the most useful. Fat in adult males may be estimated from the equation $Y_{F}=0.47$ $X-11.26(r=0.96, \mathrm{df}=16, p<0.001$ and $X=$ grams total weight). For females the equation is $Y_{F}=0.58 X-14.20(r=0.94, \mathrm{df}=21, p<0.001)$.

\section{DISCUSSION}

In Colorado, montane voles are common inhabitants of moist meadows, grassy parklands, and tundra stands of grasses and sedges from approximately 1800 to $3700 \mathrm{~m}$ elevation. Their populations show pronounced fluctuations. During the summer of 1957 we found them numerous on grass-covered solifluction terraces at $3660 \mathrm{~m}$ on Niwot Ridge near Nederland, Colorado. Numbers of individuals could be closely approached as they ran through the vegetation or fought with each other as they foraged for food. We caught eight individuals in randomly placed snaptraps providing 123 trap-nights. The following winter, digging beneath the snow-cover, we found no evidence of their presence, and the next summer we failed to catch a single individual in 360 trap-nights. In the late summer of 1968, Colvin \& C olvin (1970) found montane voles abundant and easy to catch in a recently mowed montane meadow at $2475 \mathrm{~m}$ near Boulder; the following summer, in the same meadow, we found no sign of microtine activity, although the standing hay crop was luxuriant. Others have reported similar observations (C a l h o u n, 1951, 1956; Calhoun \& Arata, 1957; Vaughan, 1969; Willard, 1960). Little is known about the physical condition of these voles during 
periods of high and low population densities, but Vaughan suggested that the low density of $M$. montanus found in 1966 near Rabbit Ears Pass, Grand County, Colorado, might have been due to the mortality induced the previous fall by exposure of voles to extreme cold and frozen low quality food.

In view of these observations, the present study was valuable in that it demonstrated that reduced food consumption, particularly when it interacts with low environmental temperature, can cause depletion of fat reserves and influence survival in montane voles. This conclusion was supported by the statistically significant differences between the terminal fat indices of starved and fed animals at each of the experimental temperatures.

Although evidence that a reduced food supply and low temperature can elicit mobilization and depletion of fat reserves and lower survival under stressful laboratory conditions does not necessarily mean that this phenomenon occurs in the montane voles' natural environment, we suggest that it does. We have already cited Vaughan's observations; other data support the idea. A 10-year study of local weather conditions by the Institute of Arctic and Alpine Research, University of Colorado (M a r r, 1968; M a r r et al. 1968a, b), revealed that snow-cover sufficient to insulate the ground in montane and alpine environments in the Colorado Front Range (Rocky Mountains) usually exists during the winter months. The mean of temperatures under the snow, recorded $30 \mathrm{~cm}$ above and $15 \mathrm{~cm}$ below ground surface, was a fairly constant $-5^{\circ} \mathrm{C}$, several degrees lower than the low test temperature. In the absence of snow, temperatures at these levels fluctuated widely. Merritt \& M e r r i t t (1978) noted that, in their study plots in a Colorado spruce-firforest, small mammals were subjected to $-25^{\circ} \mathrm{C}$ before an adequate: snow cover developed in early December. In sub-nivean runways temperatures averaged close to $0^{\circ} \mathrm{C}$. Many investigators have identified the autumnal and vernal thermal overturns as critical periods during. which mortality in voles and other mice is high (Johnson, 1951; Pruitt, 1957; Fuller et al., 1969; Whitney, 1973, 1976; V a ugh a n, 1969, 1974; S tinson, 1977).

The fat reserves of montane voles may provide only enough energy to sustain the resting metabolism of the animals for a short period of time. However, even moderately high fat levels may improve survival during the winter and during the critical periods, particularly in the spring when low night temperature, flooding of the habitat by snowmelt, and the onset of breeding coincide to stress the population. Furthermore, the generally low levels of fat which we have found in wild-caught voles (W illi a m s, 1972) suggest that the animals may be particularly; 
vulnerable to episodes of low temperature and poor food. Depletion of energy reserves may be responsible for recurrent high mortality, at least partially explaining the fluctuations in numbers which have been noted over the years.

The validity of estimating fat from intact or live weights may be questioned. We have found that the wet weight of the stomach contents of snap-trapped montane voles is highly variable. Some animals may be caught with empty stomachs; the stomach contents of others may constitute roughly fifteen percent of their total weight. Values are near the range of those for the ingesta of ruminants, cited by $\mathrm{R}$ e id et al. (1963) as being a factor introducing a major source of error in any attempt to estimate weight of fat in ruminants from live weight measurements. However, live-trapping in itself may serve to reduce this source of variability. Live-trapped voles usually remain confined for a few hours before they are released and weighed, and during this time digestion and elimination continue reducing the weight of material in the gut. The weight of ingesta in live-trapped individuals may, therefore, be relatively less variable than in intact snap-trapped animals.

\section{REFERENCES}

1. Babineau L. \& Page E., 1955: On body fat and body water in rats. Canad. J. Biochem. Physiol., 33: 970-979.

2. B a ur L. S. \& File r L. J., 1959: Influence of body composition of weanling pigs on survival under stress. J. Nutr., 69: 128-134.

3. Bergeron J. M., 1976: Caloric values of small mammals of southeastern Quebec. Acta theriol., 21: 157-163.

4. Brodie B. B., Maickel R. P. \& Stern D. N., 1965: Autonomic nervous system and adipose tissue. [In: "Handbook of physiology" Section 5. Adipose tissue]. Amer. Physiol. Soc., Washington.

5. Caldwell L. D. \& Connell C. E., 1968: A precis on energetics of the old-field mouse. Ecology, 49: 542-548.

6. Calhoun J. B., 1951: North American census of small mammals. Release No. 4. Roscoe B. Jackson Memorial Laboratory, Maine.

7. Calhoun J. B., 1956: Population dynamics of vertebrates, compilations of data. Release No. 5. U. S. Dept. Health, Education, and Welfare, Bethesda, Md.

8. Calhoun J. B. \& Arata A. A., 1957: Population dynamics of vertebrates, compilations of data. Release No. 6. U. S. Dept. Health, Education, and Welfare, Bethesda, Md.

9. Colvin M. A. \& Colvin D. V., 1970: Breeding and fecundity of six species of voles (Microtus). J. Mammal., 51: 417-419.

10. Didow L. A. \& H a y ward J. S., 1969: Seasonal variations in the mass and composition of brown adipose tissue in the meadow vole, Microtus pennsylvanicus. Canad. J. Zool., 47: 547-555.

11. Drożdż A., 1968: Digestibility and assimilation of natural foods in small rodents. Acta theriol., 13: 367-389. 
12. Elkinton J. R. \& Widdows on E. M., 1959: Effects of chronic undernutrition on body composition in the rat. Metabolism, 8: 404-417.

13. Evans D. M., 1973: Seasonal variations in the body composition and nutrition of the vole Microtus agrestis. J. Anim. Ecol., 42: 1-18.

14. Fleharty E. D., Krause M. E. \& Stinnett D. P., 1973: Body composition, energy content, and lipid cycles of four species of rodents. J. Mammal., 54: $426-438$.

15. Gę bczyńska Z., 1970: Bioenergetics of a root vole population. Acta theriol., 15: $33-66$.

16. Gilgen A., Maickel R. P., Nidodijevic O. \& Brodie B. B., 1962: Essential role of catecholamines in metabolism of free fatty acids and glucose after cold exposure. Life Sci., 1: 709-715.

17. Hall E. R. \& Kelson K. R., 1959: The mammals of North America. The Roland Press Co., 2: 547-1083. N. Y.

18. Hannon J. P. \& Larson A. M., 1961: The site and mechanism of norepinephrine-calorigenesis in cold-acclimated rats. Fed. Proc., 20: 209.

19. Hannon J. P., Evonuk E. \& Larson A. M., 1963: Some physiological and biochemical effects of cold-acclimated rats. Fed. Proc., 22: 783-787.

20. Heroux, O. 1961: Climatic and temperature-induced changes in mammals. Rev. Canad. Biol., 20: 55-68.

21. Hissa R. \& Tarkkonen H., 1969: Seasonal variations in brown adipose tissue in two species of voles and the common shrew. Ann. Zool. Fenn., 6: $444-447$.

22. How a r d W. E., 1951: Relation between low temperature and available food to survival of small rodents. J. Mammal., 32: 300-312.

23. Huth E. J. \& Elkinton J. R., 1959: Effect of acute fasting in the rat on water and electrolyte content of serum and muscle and on total body composition. Amer. J. Physiol., 196: 279-302.

24. Kleiber M., 1961: The fire of life. John Wiley and Sons: 1-454. New York.

25. Kołodziej-Banach A., 1976. Changes in fat content in an experimental population of the common vole. Acta theriol., 21: 255-266.

26. L e chleit ner R. R., 1969: Wild mammals of Colorado. Pruett Press: Boulder, Colorado.

27. M a r r J. W., 1968: Data on mountain environments. I. Front Range, Colorado, sixteen sites 1952-1953. Univ. of Colorado Press, Boulder.

28. Marr J. W., Johnson A. W., Osburn W. S., \& Knorr O. A., 1968a: Data on mountain environments. II. Front Range, Colorado, four climax regions. 1953-1958. Univ. Colo. Stud., Ser. Biol. 28: 1-169.

29. M a r J. W., Clark J. W., O sburn W. S., \& Paddock M. W., 1968b: Data on mountain environments. III. Front Range, Colorado, 1959-1964. Univ. Colo. Stud., Ser. Biol. 29: 1-181.

30. Meese G. B., 1971: Some aspects of energy balance in the bank vole Clethrionomys glareolus. J. Zool. (London), 163: 305-317.

31. Merritt J. F. \& Merritt J. M., 1978: Population ecology and energy relationships of Clethrionomys gapperi in a Colorado subalpine forest. J. Mammal., 59: 576-598.

32. Packard G. C., 1968: Oxygen consumption of Microtus montanus in relation to ambient temperature. J. Mammal., 49: 215-220.

33. Pruitt W. O., 1957: Observations on the bioclimate of some taiga mammals. Arctic, 10: $131-138$. 
34. Pucek M., 1973: Variability of fat and water content in two rodent species. Acta theriol., 18: 57-80.

35. Reid J. T., Bensadoun A., Paladines O. L. \& Niekerk B. D. H., 1963: [In: „Body composition«, H. E. Whipple, S. Silvergzweig J. Brozek eds.] Ann. N. Y. Acad. Sci., 110: 290-301.

36. Sawicka-Kapusta K., 1968: Annual fat cycle of field mice, Apodemus flavicollis (Melchior, 1834). Acta theriol., 13: 329-339.

37. Schonbaum E., Sellers E. A. \& Rimmer A., 1962: Effects of norepinephrine on blood glucose and free fatty acids in cold-adapted rats. Fed. Proc. 21: 220.

38. S e a lander J. A., 1951: Survival of Peromyscus in relation to environmental temperature and acclimation at high and low temperatures. Amer. Mid. Nat., 46: 257-311.

39. S e a l a nder J. A., 1972: Circum-annual changes in age, pelage characteristics and adipose tissue in the northern red-backed vole in interior Alaska. Acta theriol., 17: $1-24$.

40. Stins on N., 1977: Species diversity, resource partitioning and demography of small mammals in a subalpine deciduous forest. Ph. D. Thesis. Univ. of Colorado, Boulder.

41. V a ugh an T. A., 1969: Reproduction and population densities of a montane small mammal fauna. [In: "Contributions in mammalogy«, J. K. Jones, Jr. ed.] Misc. Publ., Univ. Kansas Mus. Nat. Hist. 51: 1-428.

42. Widdows on E. M. \& M c C a n ce R. A., 1956: The effects of chronic undernutrition and of total starvation on growing and adult rats. Brit. J. Nutr., 10: $363-373$.

43. Willa rd B. E., 1960: The ecology and phytosociology of the tundra curves, Trail Ridge, Colorado. M. A. Thesis. Univ. of Colorado, Boulder.

44. Williams O., 1972: Fat reserves in Microtus. J. Colo.-Wyo. Acad. Sci. $7(2-3)$ : 109. (Abstr.)

45. Williams O. \& Bird P. 1972: Criteria for distinguishing Microtus montanus and M. longicaudus, J. Colo.-Wyo. Acad. Sci. 7, 2\&3: 115. (Abstr.)

Accepted, December 12, 1978.

Paul ROCK i Olwen WILLIAMS

\section{ZMIENNOSC OTEUSZCZENIA U MICROTUS MONTANUS NANUS}

\section{Streszczenie}

Przeprowadzono serię doświadczeń nad wpływem chłodu i zróżnicowanego dostępu do pokarmu na otłuszczenie u nornika Microtus montanus nanus (M e r ri a m, 1891). Doświadczenia prowadzone były w ośmiu kombinacjach: przy dwóch poziomach temperatury -5 i $26^{\circ} \mathrm{C}$ oraz czterech poziomach zasobności diety - ad libitum, bytowym, połowie zapotrzebowania bytowego i głodzeniu. Poziom zapotrzebo- 
wania bytowego obliczono z uwzględnieniem współczynnika strawności danego rodzaju paszy, ciężaru ciała badanych zwierząt i poprawki na termoregulację.

Dostępność paszy oraz temperatura otoczenia mają lącznie wyraźny wpływ na otłuszczenie gryzoni (Tabela 1). Ich przeżywalność także była skorelowana z końcowym wskaźnikiem otłuszczenia i dostępnością diety, choć samo działanie temperatury otoczenia nie miało istotnego wpływu. Wyliczono również regresje (Tabela 2) na zależności między zawartością tłuszczu i wody, masą beztłuszczową, ciężarem tuszki po usunięciu żołądka i ciężarem całkowitym. Wyniki potwierdzają rolę tłuszczu jako substancji zapasowej, zużywanej w warunkach niedostatku pokarmu. 